\title{
Genius and Genealogy
}

\section{John Walsh}

New Zealand has a genius for genealogy. Māori trace their whakapapa back to a first canoe and many European New Zealanders track their ancestral spoor back to a first ship. Who you're from, where you're from - perhaps it isn't surprising that issues of identity are of concern in a country that is a remote fragment of larger landforms and bigger societies.

Though a preoccupation with descent may be endemic, it is, mercifully, not mandatory. For instance, I presume my forebears dwelt in various Irish bogs. Some may even have been princes of their patches of peat. Who knows, and, at this remove, who cares? The point is, clan or family history matters more to some than others; it matters most, of course, to those who evoke the past in support of territorial claims.

How important is the question of lineage in New Zealand architecture? A recent and happy coincidence of anniversaries offers some indication. Over the summer of 2005-06 three of the country's larger architecture practices celebrated fifty years of professional existence. The birthday boys - a literal description: the practices cannot muster one female partner between them - were Aucklandbased ASC Architects; Stephenson \& Turner, which has offices in Auckland and Wellington; and Warren and Mahoney, which has offices in Auckland, Wellington and Christchurch. All three practices gave some thought to how they should acknowledge their Silver Jubilee; in ascending order of pomp, let's look at what they came up with.

ASC Architects marked their milestone with an edition of their occasional twopage newsletter and a party at a café next to their city-fringe premises. This effort - comparatively modest, as we'll see - suggests a busy office, or ambivalence towards self-promotion, or a lukewarm interest in genealogy (or all three). Certainly, ASC does not have a pretentious persona, and the firm's low-key celebration of reaching fifty was in keeping with its journey there. The history of ASC serves as a reminder that, for all the debate about whether architecture is an art or a craft, it is also a business.

The practice now known as ASC Architects was established by the late Nyall Coleman. Gordon Moller, the immediate past president of the New Zealand Institute of Architects, worked for Coleman in the early 1960s and remembers his employer as, "a very urbane gentleman". A Catholic, who drew upon his social contacts to get school commissions, and a businessman who recognised the value of the repeat client, Coleman exemplified the normal type of successful twentieth century architectural practitioner. That is, he wasn't an auteur, but rather a respectable professional man. Though Coleman did well in his career he didn't make it into the Kiwi canon, and though his firm has endured his name has long since disappeared from its title (the "C" in ASC is Neil Cotton). ASC's continuity is attributable to an overlap of personnel, not to dynastic succession. 
So, no ancestor worship at ASC, and maybe its founder would have wanted it that way. Filial piety, at least formally, is more evident at Stephenson \& Turner, and self-esteem more obvious. On its fiftieth birthday S\&T hosted functions with a high suit count at the Price Waterhouse tower on Auckland's waterfront (architect: Stephenson \& Turner) and Te Papa in Wellington. Guests were welcomed by a hired raconteur and farewelled with a complimentary copy of a history commissioned by the practice (publisher: Balasoglou Books; RRP \$59.95).

Very Establishment, very corporate, very much in keeping with S\&T's reputation as a practice that does the business for finance companies, health boards and government departments. And true to the memory of the firm's progenitor, Sir Arthur George Stephenson (1890-1967), Knight of the British Empire, holder of the Military Cross, fellow of the RIBA, RAIA, and NZIA, and recipient of RIBA and RAIA Gold Medals. Now there's a father figure, and S\&T have been pretty happy to follow in the footsteps left by his big brogues.

However, there have been a couple of issues along the way. For one thing, Sir Arthur and his company were Australian, and in New Zealand Stephenson \& Turner started out as a branch office. Separation from the Australian parent eventually occurred, but not without some anxiety. It must have been tempting to signal a new start with a new name, perhaps some clever piece of architectonic lexicology. But S\&T didn't get where they are by essaying hip, and they stuck with the brand. By keeping Dad's name, Stephenson \& Turner acknowledged that they had embraced their destiny. No apparent regrets, just a hint, now and then, of wistfulness: those who have chosen to work in prose must occasionally wish they'd opted for poetry.

Warren and Mahoney's anniversary celebrations were the most ambitious of all. Birthday bashes in Christchurch, Wellington and Auckland served as launch parties for a monograph that, even priced at $\$ 110$, must have cost the practice a small fortune to produce (again the publisher is Balasoglou Books). It is the best-looking architecture book to have been published in New Zealand, though it's title is a real mouthful: New Territory/Warren and Mahoney//50 years of New Zealand Architecture. Or: Vision/Brand//History.

In this book Warren and Mahoney are both claiming and reclaiming territory. The practice wants to have it both ways: it is established (in terms of back catalogue Warren and Mahoney are the Lennon and McCartney of New Zealand architecture) and it is innovative (the practice seems to believe it has the local franchise for Environmentally Sustainable Design). What the book also announces is that the practice has worked out an answer to the question of Miles. For a while the firm's partners seemed intent on escaping the shadow of W\&M's famous (and still very much extant) founder, Sir Miles Warren. Edging down the route to professional parricide, they even changed the practice name to Architecture Warren and Mahoney.

The redundant prefix is gone now. Warren and Mahoney, as one would expect of a practice sired in origin-conscious Christchurch, has realised the advantages of its inheritance. To put it another way: if you're descended from genius, there's good reason to be a genealogist. 